\title{
Ophiuroids from the Middle Triassic (Muschelkalk) of Sadowa Góra, Jaworzno (southern Poland)
}

\author{
Dawid Surmik ${ }^{1}$, Mariusz A. Salamon², Agnieszka Chećko³, Karolina Kędroń ${ }^{4}$ \\ ${ }^{1}$ University of Silesia in Katowice, Faculty of Natural Sciences, Institute of Earth Sciences; ul. Będzinska 60, 41-200 Sosnowiec, \\ Poland; e-mail: dawid@surmik.pl (corresponding author); ORCID ID: 0000-0003-0121-9592 \\ ${ }^{2}$ University of Silesia in Katowice, Faculty of Natural Sciences, Institute of Earth Sciences, ul. Będziniska 60, 41-200 Sosnowiec, \\ Poland; e-mail: paleo.crinoids@poczta.fm; ORCID ID: 0000-0001-9399-2798 \\ ${ }^{3}$ University of Silesia in Katowice, Faculty of Natural Sciences, Institute of Earth Sciences, ul. Będzinska 60, 41-200 Sosnowiec, \\ Poland; GEOsfera Ecological Education Center, Town Hall of Jaworzno, Poland; e-mail: agnieszka.checko@um.jaworzno.pl; \\ ORCID ID: 0000-0001-5225-1408 \\ ${ }^{4}$ GEOsfera Ecological Education Center, Town Hall of Jaworzno, Poland; e-mail: karolina.kedron@um.jaworzno.pl
}

(c) 2020 Authors. This is an open access publication, which can be used, distributed and reproduced in any medium according to the Creative Commons CC-BY 4.0 License requiring that the original work has been properly cited.

Received: 1 June 2020; accepted: 27 August 2020; first published online: 31 August 2020

\begin{abstract}
Ophiuroids belonging to Aspiduriella sp., Aspiduriella similis (Eck), and Arenorbis sp. are described from the Middle Triassic (Muschelkalk) strata of the Sadowa Góra Quarry (Jaworzno) in southern Poland. This is the only Polish location where three taxa of these ophiuroids have been found in one stratigraphic horizon $\left(1^{\text {st }}\right.$ Wellenkalk). To date, only single taxa have been found in the Triassic sections of the eastern part of the Germanic Basin. Finally, other ophiuroid mass aggregations also known from Poland are presented.
\end{abstract}

Keywords: Middle Triassic, Muschelkalk, ophiuroids, Poland

\section{INTRODUCTION}

The Middle Triassic ophiuroids recorded in Silesia (southern Poland) have been the subject of numerous studies over the last 150 years. Most of these have pointed to individual findings of these organisms in Middle Triassic sediments (for details, see Radwański 2002, Salamon 2004, Surmik et al. 2014 and the literature cited therein). The latter indicated that four (or five) ophiuroid species are present in the Lower Muschalkalk. These are: Aspiduriella ludeni (von Hagenow), A. scutellata (Blumenbach), A. simlis (Eck) mentioned by Radwański (2002) as Ophiomusium(?) simile (Eck), Arenorbis squamosus (Picard), and Ophioderma hauchecorni (Eck). O. hauchecorni was mentioned by Assmann (1914) from Silesia, but both Kutscher (1940) and Radwański (2002) doubted the correctness of this assignment. Salamon et al. (2003) illustrated some individuals from the Muschelkalk of the North-Sudetic Basin identified as Aspiduriella sp. The contemporary re-examination of these specimens indicates that these forms should be associated with A. similis. Ophiuroids from Sadowa Góra were firstly mentioned by Surmik et al. (2014), who illustrated a small individual Aspiduriella sp. and a large specimen of Ophiomusium sp. Similarly, in a pop-science article, Salamon et al. (in press) assigned the largest ophiuroid from Sadowa Góra to Ophiomusium. Current observations allowed the identification of the small individual mentioned by Surmik et al. (2014) as Aspiduriella similis and the large one as Arenorbis sp.

To date, only one ophiuroid taxon has been described and illustrated from the Upper Muschelkalk in Poland. It was a form with extremely long arms found in the northern margin of the Holy Cross 
Mountains (southern Poland) and identified by Salamon \& Boczarowski (2003) as Aspiduriella sp.

Among those mentioned above, Aspiduriella ludeni, A. scutellata, and A. similis are known from more than one reliable record. In the case of the first two, these were only two localities, while A. similis has been recorded in many sections in southern Poland (both Silesia and the Holy Cross Mountains). The outcrop in Jaworzno is therefore the first where three different taxa of ophiuroids co-occur in one locality and in one stratigraphic horizon ( $1^{\text {st }}$ Wellenkalk).

\section{GEOLOGICAL FRAMEWORK}

The Sadowa Góra Quarry is situated in the northern part of Jaworzno, southern Poland (coordinates $50^{\circ} 13^{\prime} 43.7^{\prime \prime} \mathrm{N} 19^{\circ} 16^{\prime} 35.8^{\prime \prime} \mathrm{E}$; Fig. 1A, B). During the Middle Triassic, this area was part of the Germanic Basin that was connected via two sub-meridional seaways, the so-called Eastern Gate (eastern Poland) and Silesian-Moravian Gate (southern Poland) with the Tethys Ocean (for more details see Salamon \& Niedźwiedzki 2005) (Fig. 1A).
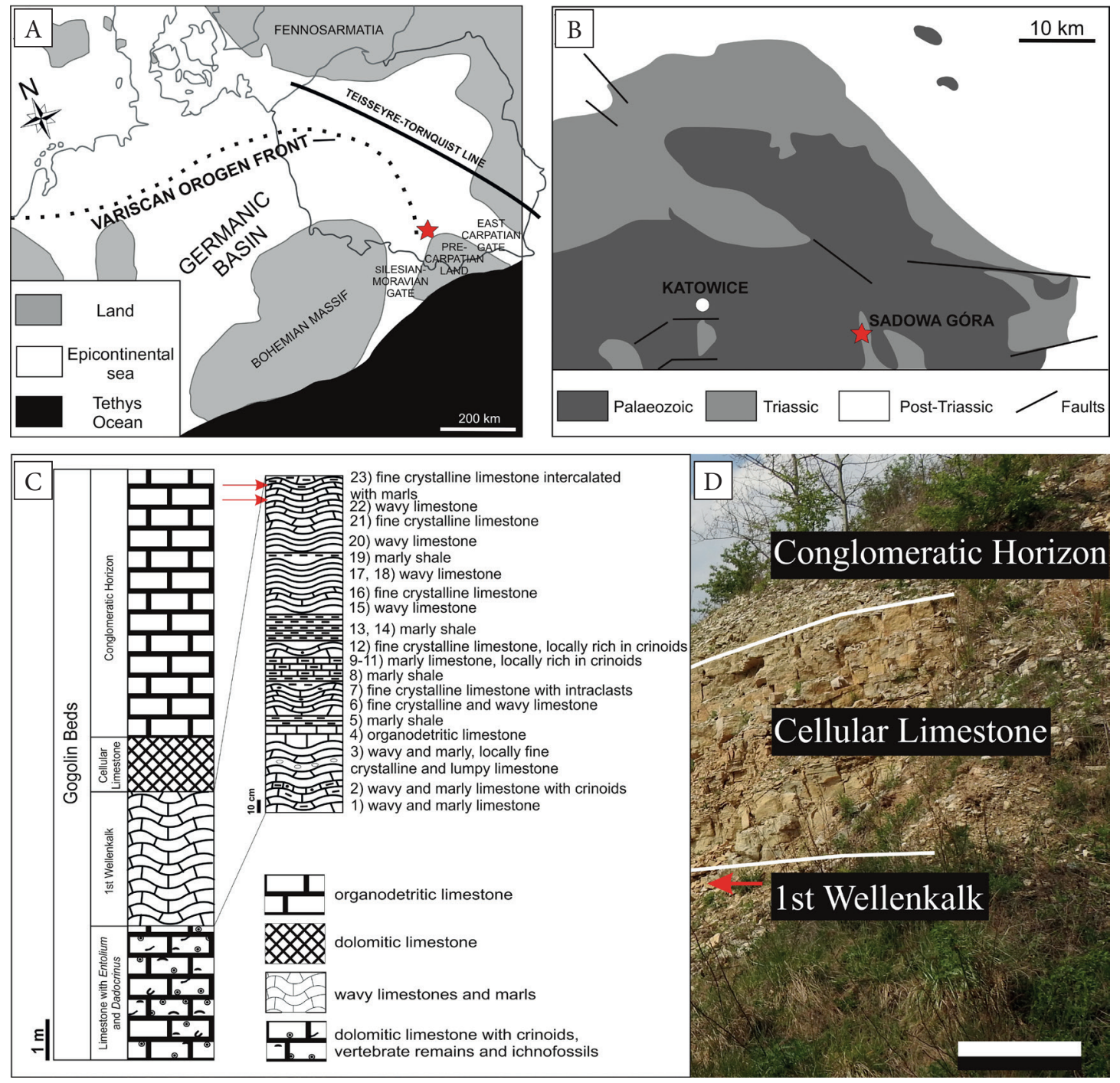

Fig. 1. Palaeogeographic map of Central Europe during Middle Triassic. Sadowa Góra Quarry is marked with red star (A). Detailed map of Upper Silesia with the Sadowa Góra Quarry marked with red star (B). Detailed section of the Middle Triassic sediments visible in Sadowa Góra Quarry (in the upper right corner detailed section of the $1^{\text {st }}$ Wellenkalk; an upper red arrow marks the occurrence of Aspiduriella similis, and a lower red arrow marks occurrence of Aspiduriella sp. and Arenorbis sp.) (C). Muschelkalk section in northern part of the Sadowa Góra Quarry. The ophiuroid bed is marked by a red arrow (D). Scale bar equals $1 \mathrm{~m}$. A and B taken and slightly modified after Zaton et al. (2008) 
The Sadowa Góra Quarry exposes carbonate sediments of the lowest part of the Muschelkalk (lowermost part of the Middle Triassic) represented by the Lower Gogolin Beds and the lowest part of the Upper Gogolin Beds. The total thickness of the Middle Triassic sequence reaches ca. $25 \mathrm{~m}$ in Sadowa Góra. In the lowermost part, the Limestones with Entolium and Dadocrinus are exposed. In the lower part, they are represented by dolomitic limestone; they are overlain by marly shales and fine crystalline limestone. They are rich in crinoids of the genus Dadocrinus and scallops Entolium. Moreover, shells of Plagiostoma striatum and arthropod ichnofossils Rhizocorallium occur. Shark teeth of Hybodus and Acrodus and the skeletal remains of sauropterygians are also found in this stratigraphic horizon (Surmik et al. 2014). Above the Limestone with Entolium and Dadocrinus, the $1^{\text {st }}$ Wellenkalk is exposed. Wavy limestones, crystalline limestones and marls with frequent bivalves, cephalopods (Salamon et al. in press) and echinoderm remains are dominant here. All ophiuroids described in the current paper were found in this stratigraphic horizon $\left(1^{\text {st }}\right.$ Wellenkalk; detailed section is described below). The Cellular Limestone is built by yellow dolomitic limestones, calcareous dolomites with calcite veins without fossils. The next is the Conglomeratic Horizon, built up of fine-crystalline, organodetritic limestones, intraclastic limestones, marls and marly shales. In the Conglomeratic Horizon, fauna is represented by numerous bivalves, gastropods, echinoderms, and remains of vertebrates. The $2^{\text {nd }}$ Wellenkalk consists of three, locally four, layers of fine-crystalline, gray, sometimes purple limestones, with rare trace fossils. According to Bojkowski (1955), the $3^{\text {rd }}$ Wellenkalk is exposed in the eastern part of the quarry, although this was not documented during the present investigations.

All of the recorded ophiuroids were found in the $1^{\text {st }}$ Wellenkalk. The lithological profile of this section is as follows (see also Fig. 1C, D): 1) $0.31 \mathrm{~m}$ : purple and gray-violet, locally marly, wavy limestones with circular dadocrinid (Dadocrinus sp.) columnals and pluricolumnals; 2) $0.10 \mathrm{~m}$ : gray, wavy, locally marly, limestone with circular dadocrinid columnals and brachial plates; 3) $0.45 \mathrm{~m}$ : wavy limestone, fine crystalline, locally lumpy, purple or gray and gray-yellow with rare dadocrinid columnals, pluri-columnals and brachial plates; 4) $0.28 \mathrm{~m}$ : gray organodetric limestone without echinoderm remains; 5) $0.15 \mathrm{~m}$ : gray marly shale with numerous, at least locally, dadocrinid ossicles; 6) $0.15 \mathrm{~m}$ : fine crystalline, wavy and thin-plate limestone, locally strongly cracked, overlapped in the middle with marly shale, with common dadocrinid columnals; 7) $0.15 \mathrm{~m}$ : fine crystalline limestone, locally with well-sorted fine, oval and ellipsoid gray intraclasts, with rare dadocrinid columnals; 8) $0.06 \mathrm{~m}$ : green marly shale with dadocrinid columnals and pluricolumnals; 9) $0.12 \mathrm{~m}$ : marly limestone with common dadocrinid ossicles; 10) $0.14 \mathrm{~m}$ : greenish marly limestone with rare dadocrinid remains; 11) $0.12 \mathrm{~m}$ : wavy marly limestone with rare dadocrinid remains; 12) $0.03 \mathrm{~m}$ : yellow-green fine crystalline limestone with common, at least locally, dadocrinid remains; 13) $0.19 \mathrm{~m}$ : light yellow marly shales with common dadocrinid ossicles; 14) $0.25 \mathrm{~m}$ : grey and yellow marly shale with dadocrinid columnals; 15) $0.18 \mathrm{~m}$ : grey wavy limestone with rare dadocrinid columnals; 16) $0.14 \mathrm{~m}$ : purple and light blue fine crystalline limestone without echinoderm remains; 17) $0.25 \mathrm{~m}$ : grey wavy, localy lumpy, limestone with common dadocrinid remains; 18) $0.19 \mathrm{~m}$ : light blue wavy limestone with macroscopically visible asteroid remains; 19) $0.03 \mathrm{~m}$ : yellow-green marly shale without echinoderms; 20) $0.30 \mathrm{~m}$ : light blue wavy limestone with dadocrinid columnals and pluri-columnals; 21) $0.18 \mathrm{~m}$ : fine crystalline limestone with dadocrinid columnals; 22) $0.22 \mathrm{~m}$ : blue wavy limestone with dadocrinid columnals, asteroid, echinoid, and ophiuroid isolated remains; 23) $0.40 \mathrm{~m}$ : fine crystalline limestone intercalated with marls with complete ophiuroids.

\section{MATERIALS AND METHODS}

The entire collection is housed at the University of Silesia in Katowice, Faculty of Natural Sciences, Poland, and registered under catalogue number: GIUS 7-3694. The classification used here is compiled after Hess (1970), Radwański (2002), Thuy \& Stöhr (2018), and terminology is adopted from Radwański (2002), Salamon \& Boczarowski (2003), Stöhr et al. (2012), and Thuy \& Stöhr (2018). 
The first ophiuroids, classified as Aspiduriella similis, were found in the $1^{\text {st }}$ Wellenkalk of Sadowa Góra in 2002 by Surmik et al. (2014). The next representatives of Aspiduriella similis were found in the same level in 2018. Individuals of Aspiduriella sp. and Arenorbis sp. were found in 2019. The ophiuroid-bearing layer is best exposed in the NW, W and NE parts of the quarry.

\section{RESULTS}

As a result of our investigations, numerous echinoderm specimens or their remains consisting of whole ophiuroid specimens, some asteroid remains, numerous crinoid columnals, pluri-columnals, and brachial plates, were collected.

The following ophiuroid (complete or nearly complete) taxa were identified: 1) Aspiduriella sp.: 6 specimens; 2) Aspiduriella similis: 44 specimens; 3) Arenorbis sp.: 1 specimen.

The state of preservation of Aspiduriella similis is different from that of Aspiduriella sp. and Arenor$b i s \mathrm{sp}$. All ophiuroids were found in one layer (layer no. 23: fine crystalline limestone intercalated with marls); however, A. similis was present on the marly surface within crystalline limestone. On the other hand, Aspiduriella sp. and Arenorbis sp. occurred on the bottom surface of this limestone. Due to this fact, the latter ophiuroids are recrystallized and this has meant that the most diagnostic elements are not visible, while still possessing large arm portions. In case of $A$. similis occurring on the marly surface, none of the observed brittle stars have their arm ends preserved, but simultaneously important diagnostic elements are well visible. None of arms shows any signs of regeneration. Their broken limbs should be treated rather as a taphonomic artifact, which occurred during the post-mortem transport of the ophiuroids.

\section{SYSTEMATIC PALEONTOLOGY}

Class: Ophiuroidea Gray, 1840

Superorder: Euryophiurida O'Hara, Hugall, Thuy, Stöhr \& Martynov, 2017

Order: Euryalida Lamarck, 1816

Family: unknown

Genus: Aspiduriella Bolette, 1998 (nomen nov. pro Aspidura Agassiz, 1835)

\section{Aspiduriella sp.}

Fig. 2A, B

Material: Six complete specimens in aboral and oral views. GIUS 7-3694.

Description: Medium-sized Aspiduriella with a central disk whose diameter ranges from $3.9 \mathrm{~mm}$ to $5.2 \mathrm{~mm}$. The central disk is pentagonal or sub-pentagonal in outline. The central primary plate is pentagonal. All other plates including the radial shields, other primary and secondary plates are not clearly visible due to the recrystallization process. The arms are very thin. Their length is from $2.5 \mathrm{~mm}$ to even $6.0 \mathrm{~mm}$. The lateral plates are narrow. The dorsal plates distinctly decrease in size distally. The podial pores are circular in shape and extend along arms.

Remarks: Several elements of the morphology of Aspiduriella sp. recorded in Sadowa Góra are similar to A. ludeni (von Hagenow) noted by Radwański (2002) from the Lower Muschelkalk of southern Poland (Silesia and Holy Cross Mountains). However, we decided not to classify the specimens from Sadowa Góra as A. ludeni due the fact that some diagnostic elements are recrystallized.

Occurrence: Lower Muschelkalk (Lower Gogolin Beds), Aegean of southern Poland (Silesia).

\section{Aspiduriella similis (Eck, 1865)}

Fig. 2C, D

1865. Aspidura similis, Eck, pp. 61-62, pl. 1, fig. 5a-c 1998. Aspiduriella similis (Eck); Bolette, pp. 401-402

Material: 44 almost complete or fragmentary specimens in aboral and oral views; three imprints composed of disks and arms in aboral (1 specimen) and oral (2 specimens) views. GIUS 7-3694.

Description: Aspiduriella similis belongs to the small-sized ophiuroids with a central disk which is round in outline. The central disk of the ophiuroids presented here are of varying diameters, ranging from 1.5 to $3.9 \mathrm{~mm}$, while the average diameter of disk equals $2.45 \mathrm{~mm}$. The dorsal side is made up of 16 major, relatively large plates, easily recognizable, accompanied by very small granules. 

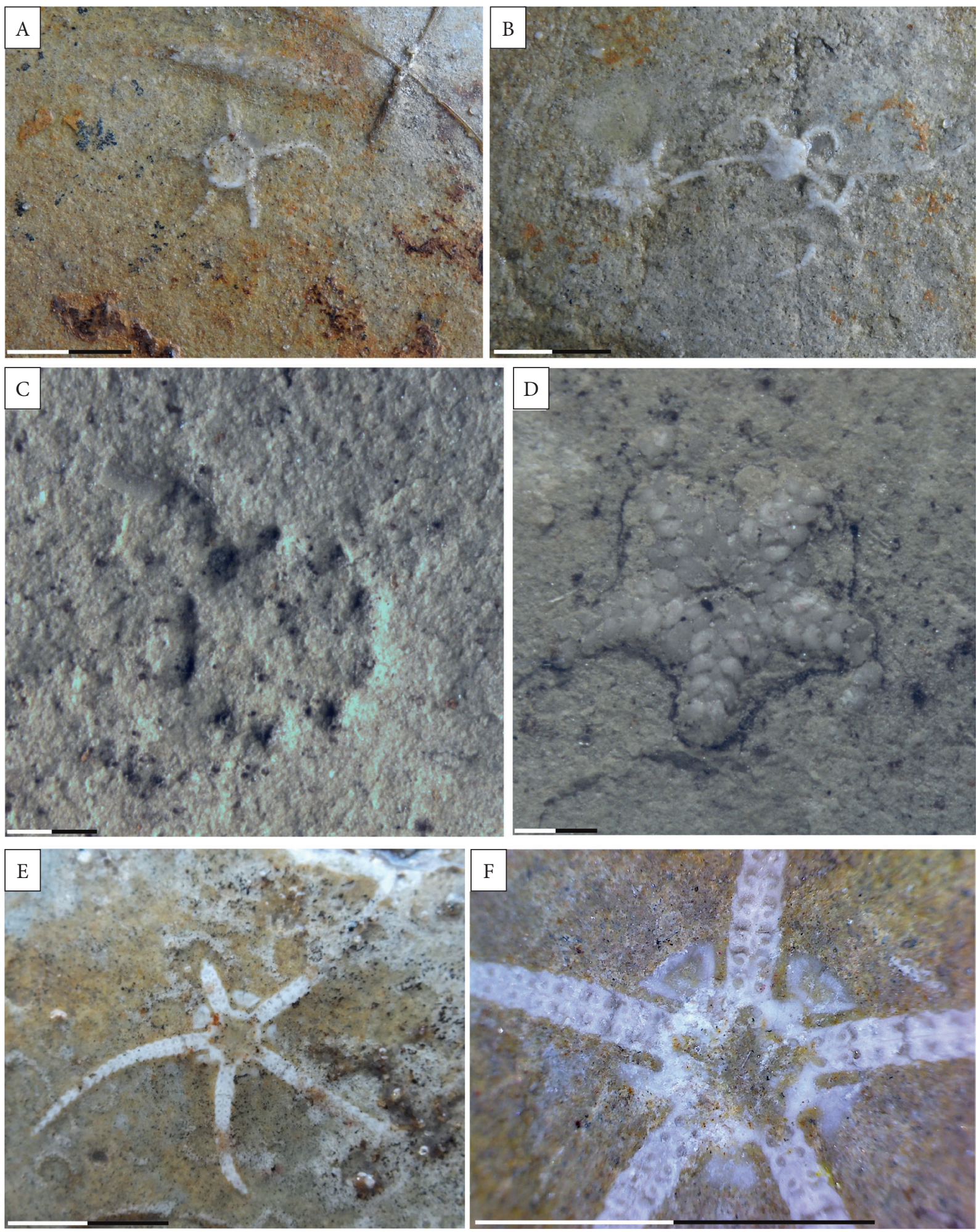

Fig. 2. Ophiuroids from Muschelkalk (Lower Gogolin Beds, $1^{\text {st }}$ Wellenkalk) of Sadowa Góra quarry: A) and B) Aspiduriella sp. Aboral view (A), oral (B; specimen on the left) and aboral views (B; specimens on the right). $C)$ and $D)$ Aspiduriella similis (Eck). Imprint of aboral view (C), and oral view (D). E) and F) Arenorbis sp. (Picard). Oral view (E), and disk enlargement (F). Scale bar equals $10 \mathrm{~mm}$ 
The granules are only located close to the line of the contact between the plates of dorsal surface of the central disc. Opposite each of the five arms are pairs of thick, drop-shaped radial shields. All radial shields have highly thickened and rounded distal edges, and there is a distinct bulge in the central part of the plate. The set of these plates forms a characteristic rosette occupying $1 / 2$ the diameter of the central disk. The inner part of the central disk is made up of five oval radial primary plates and a single central primary plate. The inner part of the central disk is made up of five oval radial primary plates and a single centrally located central primary plate. The latter is the smallest of the plates of the central disk. The arms are short, slightly extended proximally. Their length ranges from 2.0 to $4.0 \mathrm{~mm}$ (which, due to the state of preservation, is not a representative measurement). The lateral plates are relatively wide and fit tightly together. The dorsal plates are typically rhomboidal in shape, taper gradually and narrow distally on each arm. The ventral plates have a complex shape. In the proximal part of the shoulder, these ventral plates are axially elongated with slightly wider distal edges. Toward the distal part of the arm, the ventral plates become increasingly isometric. In each arm segment, axially, the ventral plate has two symmetrical, semicircular notches for the arm tentacles. These notches are located at the halfway point of all ventral plates. Each arm tentacle pore is surrounded by three plates: a ventral plate and two adjacent lateral plates. The arm tentacle pore pairs are more elliptical in the proximal part of the shoulders and become gradually circular in shape closer to the distal part of the arms. The five oral shields are located at the edge of the oral side of the center shield and form the basis of each pair of jaws. The proximal edges of oral shields are V-shaped, and the distal edges are curved. The oral frame is made of five pairs of oral plates (half-jaws), five dental plates and small block-like teeth anatomically connected to them. When viewed from the oral side, the half-jaws are highly elongated, pentagonal in outline. First ventral arm plates are T-shaped on the oral side. All arm plates and mouth frame elements are very tightly fitted together.
Remarks: During the current study, almost all of the collected individuals possess noticeably short arms, but this is rather a taphonomic artifact. On the other hand, Eck (1865, pl. 1, fig. 5a-c) illustrated specimens with very long arms and their length is more than double the disk diameter. Research work on the Aspiduriella similis collection presented in this work has revealed that all specimens are more or less damaged. This is especially true for delicate parts such as the ends of arms. This phenomenon is not unusual in echinoderms and, as numerous studies show, they are the result of both in vivo and post-mortem events (Gorzelak \& Salamon 2013). It is particularly well visible in the very important collection from Wojkowice (Upper Silesia), including 428 specimens, where numerous specimens were found showing the regeneration of arms after their in vivo damage ( $\mathrm{Za}-$ toń et al. 2008).

Hess (1965) included A. similis into Ophiomusiun (O.? simile), although Eck (1865) originally referred to it as Aspidura similis. According to Zatoń et al. (2008), A. similis should be classified as Aspiduriella, not Ophiomusium, due to morphological differences between these genera (e.g., short arms of Aspiduriella, podial pores on its arms, etc.).

Occurrence: Lower Muschelkalk (Lower Gogolin Beds), Aegean-Pelsonian of southern Poland (Silesia, Holy Cross Mountains). It is highly probable that Aspiduriella sp. described by Salamon et al. (2003, fig. 2b, c) from the North-Sudetic Basin, with its morphological features as presented above, belongs to A. similis.

Order: Amphilepidida O'Hara, Hugall, Thuy, Stöhr \& Martynov, 2017

Family: Ophiolepididae Ljungman, 1867

Genus: Arenorbis Hess, 1970

\section{Arenorbis sp.}

Fig. 2E, F

Material: One complete specimen in oral view. GIUS 7-3694.

Description: A relatively large ophiuroid with a disk diameter of $6.0 \mathrm{~mm}$. The central disk is round. The borders between disk plates are not 
visible due to recrystallization. The specimen was preserved in the post-mortem position with the mouth frame parts wide open. The arms are thin and exceptionally long; their max. length is $12.0 \mathrm{~mm}$. The lateral plates are extremely narrow. Remarks: Arenorbis sp. from the Sadowa Góra Quarry resembles Arenorbis squamous (Picard). This is the largest ophiuroid among all those previously documented in the eastern part of the Germanic Basin. Piotrowski (1986) and Radwański (2002) also illustrated forms with a central disk diameter of about $6 \mathrm{~mm}$. However, stratigraphic and geographic provenance, body size, or proportion of arms to disk, are poor criteria for a species identification.

Occurrence: Lower Muschelkalk (Lower Gogolin Beds), Aegean of southern Poland (Silesia).

\section{HIGH-DENSITY POPULATIONS OF TRIASSIC OPHIUROIDS IN POLAND}

There is a substantial amount of data to suggest that ophiuroid mass aggregations were common in shallow waters until the Jurassic, and then dropped significantly to the end of the Mesozoic (e.g., Aronson 1992). Confirmation of this fact seems to be found in the Triassic of Poland.

Assmann (1914) mentioned numerous individuals of Arenorbis squamosus (ca. 200 individuals) from the locality of Rojca near Bytom, although this author did not explicitly state whether they formed accumulations on one (several slabs?), and whether they were complete or rather disarticulated. Piotrowski \& Liszkowski (1981) and Piotrowski (1986) were the first to mention mass aggregations of Arenorbis squamous from the Muschelkalk of southern Poland. At first, Piotrowski \& Liszkowski (1981) illustrated two slabs from Będzin (Lower Muschelkalk) with 120 specimens and 130 specimens. Then Piotrowski (1986) illustrated a slab with individuals from the Diplopora Beds of Wojkowice Kościelne. Radwański (2002) claimed that the slab from Wojkowice Kościelne is housed in the University of Silesia, Faculty of Natural Sciences, Poland, which is unfortunately not the case. In both of the photos presented by the latter authors, in most cases, complete individuals are visible and represented mainly by juvenile, semi-adult and adult individuals which supposedly represent all of theontogenetic stages of the species.

Radwański (2002) was the first to demonstrate Aspiduriella ludeni mass aggregations. Earlier mentions only noted their individual occurrences (e.g., von Hagenow 1846, Kutscher 1940, Hess 1965). According to Radwański (2002) A. ludeni preferably lived in their own, monospecific communities, lacked any natural predators, and were opportunistic in terms of the habitats they occupied.

Aspiduriella similis formed the most numerous mass accumulations of ophiuroids in the eastern part of the Germanic Basin. This species has been noted at several sites in the Holy Cross Mountains and Silesia (Boczarowski \& Salamon 2000, Salamon 2004, Salamon \& Zatoń 2004, Zatoń et al. 2008). Interestingly, Zatoń et al. (2008) also mentioned $A$. similis from the Conglomeratic Horizon of Upper Gogolin Beds from Sadowa Góra. These ophiuroid assemblages were all polyindividual and monospecific. In all of the sections mentioned above, the $A$. similis were preserved as articulated specimens.

\section{CONCLUSIONS}

In the Middle Triassic (Muschelkalk) layer of the Sadowa Góra Quarry in southern Poland, three ophiuroid taxa were collected [(Aspiduriella sp., A. similis (Eck), and Arenorbis sp.]. Aspiduriella sp. and Arenorbis sp. were observed on the bottom surface of fine-crystalline limestone, and A. similis individuals were found on the surface of the marly intercalation occurring within this limestone. Sadowa Góra is the only site in Poland where three different ophiuroid taxa have been found.

The authors would like to thank Ms. Karolina Paszcza for technical support during preparation of the current manuscript. Zuzanna Wawrzyniak, M.Sc. is acknowledged for the preparation of the photos. Dr Andrzej Boczarowski is also thanked for some valuable suggestions concerning ophiuroids. The reviewers (Dr Ben Thuy and another anonymous one) are acknowledged for their valuable comments that helped to improve this article. 


\section{REFERENCES}

Agassiz L., 1835. Prodrome d'une Monographie des Radiaires ou Echinodermes. Mémoires de la Société des Sciences naturelles de Neuchâtel, 1, 168-199.

Aronson R.B., 1992. Biology of a scale-independent predator-prey interaction. Marine Ecology Progress Series, 89, $1,1-13$.

Assmann P., 1914. Beitrag zur Kenntnis der Stratigraphie des oberschlesischen Muschelkalks. Jahrbuch der Königlich Preußischen Geologischen Landesanstalt, 34, 1, 268-340.

Boczarowski A. \& Salamon M.A., 2000. Kompletne wężowidła jako wskaźnik warunków sedymentacji warstw gogolińskich Górnego Śląska. [in:] Historia basenów sedymentacyjnych a zapis paleontologiczny: XVII konferencja paleontologów: 21-23.IX.2000 Kraków, AGH, Kraków, 20-21.

Bojkowski K., 1955. Dolny wapień muszlowy w okolicy Szczakowej. Biuletyn Instytutu Geologicznego, 97, 229-270.

Bolette D.P., 1998. Taxonomic note: Aspiduriella nom. n. for the genus Aspidura Agassiz, 1835 (Echinodermata: Ophiuroidea: Ophiuridae); preoccupied by Aspidura Wagler, 1830 (Reptilia: Serpentes: Colubridae). Journal of Paleontology, 72, 2, 401-402.

Eck H., 1865. Über die Formationen des bunten Sandsteins und des Muschelkalks in Oberschlesien und ihre Versteinerungen. J.F. Starcke, Berlin.

Gorzelak P. \& Salamon M.A., 2013. Experimental tumbling of echinoderms-taphonomic patterns and implications. Palaeogeography, Palaeoclimatology, Palaeoecology, 386, 569-574.

Gray J.E., 1840. A synopsis of the genera and species of the class Hypostoma Asterias (Linn.). Annals and Magazine of Natural History, 6, 275-290.

Hagenow F. von, 1846. Aspidura Ludeni. Paläontographica, $1,21-22$.

Hess H., 1965. Trias-Ophiuren aus Deutschland, England, Italien and Spanien. Mitteilungen der Bayerischen Staatssammlung für Paläontologie und Historische Geologie, 5, 2, 151-177.

Hess H., 1970. Ein neuer Schlangenstern (Aplocoma mutata n.sp.) aus dem Hettangien von Ceilhes (Hérault) und Bemerkungen über "Ophioderma" squamosa aus dem $\mathrm{Mu}$ schelkalk. Eclogae Geologicae Helvetiae, 63, 3, 1059-1067.

Kutscher F., 1940. Ophiuren-Vorkommen im Muschelkalk Deutchlands. Zeitschrift der Deutschen Geologischen Gesellschaft, 92, 1, 1-18.

Lamarck J.-B., 1816. Histoire naturelle des animaux sans vertèbres, présentant les caractères généraux et particuliers de ces animaux, leur distribution, leurs classes, leurs familles, leurs genres, et la citation des principales espèces qui s'y rattachent. Tome second. Verdière, Paris.

Ljungman A.V., 1867. Ophiuroidea viventia hucusque cognita enumerat. Öfversigt af Kongliga Vetenskaps-Akademiens Förhandlingar, 23, 9, 303-336.
O’Hara T.D., Hugall A.F., Thuy B., Stöhr S. \& Martynov A., 2017. Restructuring higher taxonomy using broad-scale phylogenomics: The living Ophiuroidea. Molecular Phylogenetics and Evolution, 107, 415-430.

Piotrowski A., 1986. Ophioderma squamosum (Picard, 1858). [in:] Malinowska L. (ed.), Geology of Poland. Vol. 3. Atlas of guide and characteristic fossils. P. 2a, Mesozoic, triassic, Wydawnictwa Geologiczne, Warszawa, 56-58.

Piotrowski A. \& Liszkowski J., 1981. Występowanie wężowideł w wapieniu muszlowym Wyżyny Śląsko-Krakowskiej. [in:] Fauna i flora triasu obrzeżenia Gór Świętokrzyskich $i$ Wyżyny Śląsko-Krakowskiej. Materiały V Krajowej Konferencji Paleontologów, Kielce-Sosnowiec, 58-60.

Radwański A., 2002. Triassic brittlestar beds of Poland: a case of Aspiduriella ludeni (v. Hagenow, 1846) and Arenorbis squamosus (E. Picard, 1858). Acta Geologica Polononica, 52, 4, 395-410.

Salamon M.A., 2004. High-density populations of the Triassic ophiuroid Aspiduriella similis (Eck) from the Holy Cross Mountains (central Poland): a preliminary report. Freiberger Forschungshefte Paläontologie, Stratigraphie, Fazies, C502, 12, 1-14.

Salamon M.A. \& Boczarowski A., 2003. The first record of Aspiduriella (Ophiuroidea) in the Upper Muschelkalk of Poland. Geological Quarterly, 47, 3, 307-310.

Salamon M.A. \& Niedźwiedzki R., 2005. An explanation for low endemism of Triassic crinoids from the epicontinental Germanic Basin, Poland. Geological Quarterly, 49, 3, 331-338.

Salamon M.A. \& Zatoń M., 2004. Masowe nagromadzenia artykułowanych szkieletów wężowideł w osadach środkowego triasu Górnego Śląska i ich implikacje tafonomiczne. Przeglad Geologiczny, 52, 10, 997-1001.

Salamon M.A., Niedźwiedzki R. \& Walter R., 2003. New data on Middle Triassic echinoderms from the Sudetes Mountains. Geological Quarterly, 47, 2, 133-139.

Salamon M.A., Chećko A. \& Kędroń K., in press. Unikatowa fauna stenohalinowa $\mathrm{z}$ osadów środkowotriasowych kamieniołomu Sadowa Góra (Jaworzno). Przyroda Górnego Śląska.

Stöhr S., O’Hara T.D. \& Thuy B., 2012. Global Diversity of Brittle Stars (Echinodermata: Ophiuroidea). PLOS ONE, 7, e31940.

Surmik D., Skreczko S. \& Wolny M., 2014. The results of palaeontological excavations in the Sadowa Góra quarry (2012-14). Contemporary Trends in Geoscience, 3, 91-100.

Thuy B. \& Stöhr S., 2018. Unravelling the origin of the basket stars and their allies (Echinodermata, Ophiuroidea, Euryalida). Scientific Reports, 8, 8493.

Zatoń M., Salamon M.A., Boczarowski A. \& Sitek S., 2008. Taphonomy of dense ophiuroid accumulations from the Middle Triassic of Poland. Lethaia, 41, 1, 47-58. 